\title{
Physiochemical and proximate analysis of Carum carvi.
} L.

\author{
Mohamed N. Abdalaziz ${ }^{1,3 *}$, Mahmoud M. Ali ${ }^{1}$, Mohamed I. Garbi ${ }^{2}$ and Ahmed S. Kabbashi ${ }^{2}$ \\ ${ }^{1}$ Department of Chemistry, Faculty of Pure and Applied Science, International University of Africa, P.O. Box 2469, \\ Khartoum, Sudan. \\ ${ }^{2}$ Department of Microbiology, Faculty of Medical Laboratory Sciences, International University of Africa, P.O. Box 2469, \\ Khartoum, Sudan. \\ ${ }^{3}$ Medicinal and Aromatic Plants and Traditional Medicine Research Institute (MAPTMRI), P.O. Box 2404, National \\ Center for Research, Khartoum, Sudan.
}

Accepted 10 April, 2017

\begin{abstract}
Carum carvi. L. was used traditionally in different populations for many medical complains. The seeds are used for culinary purposes and medicinal treatment. The study was aimed to investigate the proximate analysis of Carum carvi and physiochemical properties of seeds oil. The oil was extraction by petroleum ether $\left(60\right.$ to $\left.80^{\circ} \mathrm{C}\right)$ using a Soxhlet apparatus. Carum carvi L. seeds oil showed $4.5 \%$ yield of fixed oil. Some of proximate analysis of seeds such as ach, fatty acid, fiber, moisture, protein and carbohydrate were given $(9.29 \pm 0.52,1.67 \pm 0.16,46.85 \pm 0.49,3.205 \pm 0.021,31.12 \pm 0.46$ and $7.87 \pm 0.67$, respectively). The physico-chemical properties of the extracted fixed oil such as density, refractive index, viscosity, color, acid value, peroxide value, saponification value, un saponification matter and iodine value were given (35.133 \pm $0.208,0.916 \pm 0.02,56.947 \pm 0.002,1.465 \pm 0.002,0.63 \pm 1.14,98.737 \pm 0.78,188.303 \pm 1.38,3.01 \pm 0.47$ and $4.45 \pm 0.48$, respectively). It was concluded that physico-chemical parameters were analyzed can be used to determine the quality of fixed oils.
\end{abstract}

Keywords: Carum carvi. L., seeds, proximate, physiochemical.

*Corresponding author. E-mail: mohdnasr19@gmail.com.

\section{INTRODUCTION}

More than 1000 plant species are known for their anticancer potential. Some plants extracts were defined as effective in treating cancer, there action was attributed to additional or synergistic effect of compounds present in the extract. In consequence, the cytostatic effect of the extract observed in tumor cells seems to be more effective than the effect of isolated and biologically active compounds (Kallio et al., 1994)

Carum carvi $\mathrm{L}$. belonging to the family: Apiaceae, is one of the earliest cultivated herbs in Asia, Africa and Europe. In folk medicine, this plant is used as a carminative for stomach disorders, diarrhea, and colic, as well as particularly in veterinary medicine (Gruenwald et al., 2004).

Caraway has a long history of use as a household remedy especially in the treatment of digestive complaints where its antispasmodic action soothes the digestive tract and its carminative action relieves bloating caused by wind and improves the appetite (Grieve, 1984; Bown, 1995; Chevallier, 1996). It is often added to laxative medicines to prevent griping (Bown, 1995). The seed is antiseptic, aromatic, anaesthetic, anodyne, antianxiety, diuretic, mildly expectorant, fungicidal, muscle relaxant, soporific, tonic, emmenagogue, expectorant, galactogogue and stimulant (Grieve, 1984; Foster and Duke, 1990). Also C. carvi are used in traditional Sudanese medicine and other folk medicines as a carminative, since it is effective against spasmodic gastrointestinal complaints, flatulence, irritable stomach, indigestion, lack of appetite, and dyspepsia in adults (Laribi, 2010).

Density of seed/vegetable oils is dependent on their 
fatty acid composition, minor components and temperature (Fakhri and Qadir, 2011). The difference in the density of the reviewed oils may be due to the refined and unrefined characteristics of the oils. Viscosity plays an important role in determining the structure of liquids and increased with the molecular weight and decreased with increasing unsaturated level and high temperature (Nourrechni et al., 1992). More viscous oil is the better to use as lubricant (Belewu et al., 2010). And the oils with low viscosity value indicate that they are light and so probably highly unsaturated; the high value might be as a result of suspended particles still present in the crude oil sample (Nangbes et al., 2013).

Moisture: not more than $10 \%$, total ash on dry mass: not more than $8 \%$, acid insoluble ash on dry basis: not more than $1.5 \%$, volatile oil content on dry basis, $\mathrm{ml} / 100 \mathrm{~g}$ : not less than 2.5, alcohol-soluble extractive: not less than $2 \%$, water-soluble extractive: not less than $12 \%$ (Indian Standards, 2011).

Free fatty acid is the percentage by weight of a specified fatty acid (e.g. percent oleic acid) (Nielson, 1994). Free fatty acids estimate the amount of oil that will be lost during refining steps designed to remove fatty acids (Weiss, 1983). High levels of free fatty acids especially linoleic acids are undesirable in finished oils because they can cause off-favors and shorten the shelf life of oils. The quantity of free fatty acid in oil is an indicator of its overall quality. They may be formed through hydrolysis or in the advanced stages of oxidation. An excessive amount of free fatty acids lowers the smoke point of oil and will cause 'popping' of the oil during cooking (Overhults et al., 1973). In refined vegetable oils, the lower the free fatty acid the more acceptable the oil is to man in terms of palatability.

Acid value gives an indication of the quality of fatty acids in oil. The value however accounted for the presence of free fatty acids in the oils as an indicator of the presence and extent of hydrolysis by lipolytic enzymes and oxidation (Gordon et al., 1993). Low acid value in oil indicates that the oil will be stable over a long period of time and protect against rancidity and peroxidation. This could be attributed to presence of natural antioxidants in the seeds such as vitamins $C$ and $A$ as well as other possible phytochemical like flavonoids. Acid value is used as an indicator for edibility of an oil and suitability for use in the paint and soap industries (Aremu et al., 2006a). High acid value in oil (e.g. luffa gourd) showed that the oil may not be suitable for use in cooking (edibility), but however, be useful for production of paints, liquid soap and shampoos (Akintayo, 2004; Aremu et al., 2006a). Also appreciable acid value of oils is an indication that the plant might be poisonous for livestock (Aremu et al., 2006a).

The saponification value is a measure of oxidation during storage, and also indicates deterioration of the oils. An increase in saponification value in oil increases the volatility of the oils. It enhances the quality of the oil because it shows the presence of lower molecular weight components in $1 \mathrm{~g}$ of the oil which will yield more energy on combustion (Engler and Johnson, 1983). The low saponification value is an indication that the oil may not be suitable for soap making, oil-based ice-cream and shampoos. It has been reported by Pearson (1976) that oils with high saponification values contain high proportion of lower fatty acids. Therefore, the low saponification value of some oils under reviewed indicated that they contain high proportion of higher fatty acid and can be regarded as non-edible oils.

The iodine value is a measure of the degree of unsaturation and it is an identity characteristic of seed oils, making it an excellent raw materials for soaps cosmetics industries (Hamilton, 1999). The iodine value could be used to quantify the amount of double bond present in the oil which reflects the susceptibility of the oil to oxidation. Oils with iodine value less than $100 \mathrm{gl} / 2 / 100$ $\mathrm{g}$ of oil are non-drying oils; correspondingly, Aremu et al. (2006a) reported that the lower the iodine value less the number of unsaturated bonds; thus the lower the susceptibility of such oil to oxidative rancidity. Therefore, non-drying oils are not suitable for ink and paint production due to their non-drying characteristics but may be useful in the manufacture of soaps (Kochhar, 1998) and can be regard as liquid oil. A good drying oil should have iodine value of 130 and above. High iodine value is a pointer to the presence of high percentage of unsaturated fatty acids in the seed oil; as such amount of iodine that will be absorbed by the unsaturated acids would be higher (Eze, 2012) and oils with such characteristic may therefore be find useful as raw materials in the manufacture of vegetable oil-based ice cream (Oderinde et al., 2009).

Peroxide value (P.V) is the most common indicator of lipid oxidation. The unrefined vegetable oils are characterized by greater PV, compared to refined oils. High values of PV are indicative of high levels of oxidative rancidity of the oils and also suggest absence or low levels of antioxidant; certain antioxidants may, however, be used to reduce rancidity such as propygadlate and butyl hydroxyl anisole (Kyari, 2008). The WHO/FAO (1994) stipulated a permitted maximum peroxide level of not more than 10 mequivalent of oxygen $/ \mathrm{kg}$ of the oils; therefore, some of the oils reviewed may not be suitable for consumption.

High unsaponifiable matter content of fats and oils has been reported to be an indication of adulteration or contamination. This may be due to the presence of fuel or lubricating oils in the oil sample (Ihekoronye and Ngoddy, 1985). Therefore, the study was aimed to investigate physiochemical and proximate analysis of fixed oil of carum carvi L. (seeds).

\section{MATERIALS AND METHODS}

\section{Plant materials}

The Caraway (Carum carvi L.), was collected from Khartoum 

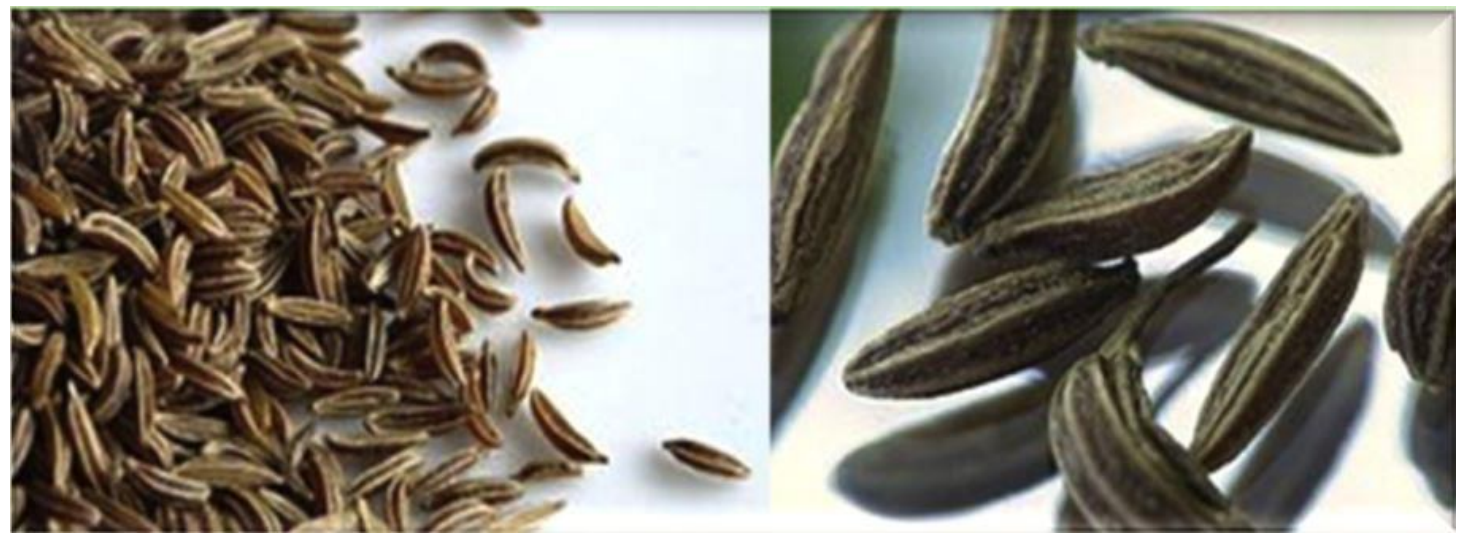

Figure 1. Carum carvi. L seeds.

central Sudan during September to October 2016, and the plant was kindly identified and authenticated by Medicinal and Aromatic Plants and Traditional Medicine Research Institute (MAPTMRI) in Khartoum, Sudan. Seeds were air-dried, under the shade, pulverized and stored prior to extraction. Shade with good ventilation and then ground finely in a mill and kept in the herbarium until oil extract preparation (Figure 1).

\section{Extraction of oil}

Air-dried seeds of Caraway (Carum carvi L.), was separately powdered and extracted with $1 \mathrm{~L}$ of petroleum ether $\left(60\right.$ to $\left.80^{\circ} \mathrm{C}\right)$ using a Soxhlet apparatus. This process of extraction was repeated for $6 \mathrm{~h}$, the petroleum ether distilled out by distillation assembly, then concentrated by hot plate drying and air-drying at temperature of $40 \pm 2^{\circ} \mathrm{C}$.

Yield $\%=($ weigh of extract $/$ weigh of sample $) \times 100$

\section{Proximate analysis}

Proximate analysis was determined according to A.O.A.C. (2003) as follows:

\section{Determination of moisture content}

Moisture was determined by oven drying method. 100 grams of well-mixed sample was accurately weighed in clean, dried crucible (W1). The crucible was allowed in an oven at 100 to $105^{\circ} \mathrm{C}$ for 6 to $12 \mathrm{~h}$ until a constant weight was obtained. Then the crucible was placed in the desiccator for $30 \mathrm{~min}$ to cool. After cooling it was weighed again (W2). The percent moisture was calculated by following formula:

Moisture\% $=(\mathrm{W} 1-\mathrm{W} 2) \mathrm{Wt}$. of sample $\times 100$

Where:

W1 = Initial weight of (crucible + Sample)

W2 $=$ Final weight of (crucible + Sample)

\section{Determination of ash}

Weight of clean empty crucible was noted (W1). Two gram of each of sample was taken in crucible (W2). The crucible was placed in muffle furnace at $550^{\circ} \mathrm{C}$ for 2 to $4 \mathrm{~h}$. The appearances of gray white ash indicate complete oxidation of all organic matter in the sample. After ashing furnace was switched off. The crucible was cooled and weighed $\left(\mathrm{W}_{3}\right)$. Percent ash was calculated by following formula:

Ash $\%=($ W3-W1 $) /$ Wt. of sample $\times 100$

\section{Determination of protein}

Protein in the sample was determined by Kjeldahl method. Two hundred milligram of dried samples was taken in $100 \mathrm{ml}$ digestion flask. Then $3.5 \mathrm{ml}$ of concentrated sulfuric acid and $0.4 \mathrm{~g}$ of catalyst mixture (potassium sulfate + cupric sulfate $8: 1$ ) were added. The flask was heated in electrical heater for $2 \mathrm{~h}$. The sample was cooled and diluted and then placed in the distillation apparatus. A $20 \mathrm{ml}$ of $40 \% \mathrm{NaOH}$ solution were added and the mixture was heated and distilled until $20 \mathrm{ml}$ were received in $100 \mathrm{ml}$ conical flask, the ammonia evolved was received on $10 \mathrm{ml}$ of $4 \%$ boric acid solution.

Using 3 to 4 drops of universal indicator (Bromo cresol green and methyl red in alcohol). The trapped ammonia was titrated against $(0.02 \mathrm{~N}) \mathrm{HCl}$ until the appearance of pink color. Percent crude protein content of the sample was calculated by using the following formula:

Nitrogen $(\mathrm{N}) \%=$

Volume of $\mathrm{HCl} \times 0.02 \times 14 \times 100$

Wt of sample $\times 1000$

Crude Protein $\%=6.25 \times \% \mathrm{~N}$

Where:

$0.02=$ Normality of $\mathrm{HCl}$

$14=$ Milli equivalent weight of Nitrogen

$6.25=$ Correction factor

\section{Determination of crude fat}

Crude fat was determined by ether extract method using Soxhlet apparatus. Approximately two grams of moisture free sample was wrapped in filter paper, placed in fat free thimble and then introduced in the extraction tube. Weighed, cleaned and dried the receiving beaker was filled with petroleum ether and fitted into the apparatus. Turned on water and heater to start extraction. After $6 \mathrm{~h}$ siphoning allow ether to evaporate and disconnect rounded flask 
before last siphoning and evaporate ether on water bath. And then weight the round flask with the remaining oil (Ether extract). The percent crude fat was determined by using the following formula:

$$
\text { Crude fat } \%=\frac{\text { Wt. of ether extract }}{\text { Wt. of sample }} \times 100
$$

\section{Determination of crude fiber}

A moisture free and ether extracted sample of crude fiber made of cellulose was first digested with dilute $\mathrm{H}_{2} \mathrm{SO}_{4}$ and then with dilute $\mathrm{KOH}$ solution. The undigested residue collected after digestion was ignited and loss in weight after ignition was calculated.

Procedure: Using the fiberic system, weighed $2 \mathrm{~g}$ sample of defatted sample $\left(\mathrm{W}_{0}\right), 150 \mathrm{ml}$ of preheated sulfuric acid solution added and then heated to boiling for $30 \mathrm{~min}$, and then the filtered residue was washed three times with hot distilled water to completely ensure the removal of acid from sample. The same procedure was used for alkali digestion by using $\mathrm{KOH}$ instead of $\mathrm{H}_{2} \mathrm{SO}_{4}$. The sample was dried in an oven at $150^{\circ} \mathrm{C}$ for $1 \mathrm{~h}$. Then the sample was allowed to cool in a desiccator and weighed $\left(\mathrm{W}_{1}\right)$. The sample crucibles was Kept in muffle furnace at $550^{\circ} \mathrm{C}$ for 3 or $4 \mathrm{~h}$. The sample was cooled in desiccator and weighed again $\left(W_{2}\right)$, calculations were done by using the formula:

Crude fiber\% $=\left(W_{1}-W_{2}\right) W_{0} \times 100$

\section{Total carbohydrates}

The total carbohydrates were calculated by subtracting the sum of fat, protein, moisture, fiber and ash contents from 100.

\section{Physiochemical analysis}

Physiochemical analysis was determined according to A.O.A.C. (2003) as follows:

\section{Determination of density}

The densities of the oils were determined by ASTM method D 1298 - (99). The sample was brought to a specified temperature and a test portion was transferred to a hydrometer cylinder that had been brought to approximately the same temperature. The appropriate hydrometer, also at a similar temperature, was lowered into the test portion and allowed to settle. After temperature equilibrium has been reached, the hydrometer scale reading and the temperature of the test portion were taken. The observed hydrometer reading was reduced to the reference temperature by means of a petroleum measurement table. Any hydrometer correction was applied to the observed reading and the corrected hydrometer scale reading recorded to the nearest $0.1 \mathrm{~kg} / \mathrm{m}^{3}$ as density.

\section{Determination of viscosity}

Viscosity is the resistance to the flow and it was determined by using viscometer. The viscosity of the respective oil was determined by using viscometer with a selection of spindle number four which was properly fixed to the holder. The container having the oil was carefully placed below the rotor holding the spindle. The spindle was allowed to immerse into the oil inside the container. The meter was turned on and adjusted to a speed of $6 \mathrm{~m} / \mathrm{s}$. then the spindle was allowed to rotate in the oil for a period of 30 min until stable reading displayed on the meter's display screen. The viscosity value of the oil was measured in centipoises.

\section{Determination of refractive index}

Abbey refractometer was used in this determination. A drop of the sample was transferred into a glass slide of the refractometer. Water at $30^{\circ} \mathrm{C}$ was circulated round the glass slide to keep its temperature uniform. Through the eye piece of the refractometer, the dark portion viewed was adjusted to be in line with the intersection of the cross. At no parallax error, the pointer on the scale pointed to the refractive index. This was repeated and the mean value noted and recorded as the refractive index.

\section{Determination of color}

Melt the sample if it is not already liquid and filter the oil through a filter paper to remove any impurities and traces of moisture. Make sure sample is absolutely clear and free from turbidity. Clean the glass cell of desired size with carbon tetrachloride and allow it to dry. Fill it with the oil and place the cell in position in the tintometer. Match the color with sliding red, yellow and blue colours.

\section{Determination of iodine value}

$0.5 \mathrm{~g}$ of oils was weighed into conical flask and $20 \mathrm{ml}$ of carbon tetrachloride was added to dissolve the oil. $25 \mathrm{ml}$ of Wij's reagent was added to the flask using a measuring cylinder in a fume chamber. Stopper was then inserted and the content of the flask was vigorously swirled.

The flask was then placed in the dark for $35 \mathrm{~min}$. At the end of this period, $20 \mathrm{ml}$ of $10 \%$ aqueous potassium iodide and $100 \mathrm{ml}$ of water were added using a measuring cylinder. The content was titrated with $0.1 \mathrm{M}$ sodium thiosulphate solution. Few drops of $1 \%$ starch indicator were added and the titration continued by adding the sodium thiosulphate drop wise until coloration disappeared after vigorously shaking. The same procedure was used for the blank test. The lodine Value (I.V) is given by the expression:

lodine Value $(\mathrm{I} . \mathrm{V})=12.69 \mathrm{C}(\mathrm{V} 1-\mathrm{V} 2) / \mathrm{M}$

Where:

$\mathrm{C}=$ concentration of sodium thiosulphate

$\mathrm{V} 1$ = volume of sodium thiosulphate used for blank

V2 $=$ volume of sodium thiosulphate used for determination

$\mathrm{M}=$ mass of sample

$12.69=$ Constant

\section{Determination of the saponification value}

An American Standard for Testing Material (ASTM) method- (D 5558-95) was used for the determination of the Saponification Values of the vegetable oils. 2 to $5 \mathrm{~g}$ of the oil was weighed into the Erlenmeyer flask or conical flask. $25 \mathrm{ml}$ of $0.5 \mathrm{M}$ ethanolic $\mathrm{KOH}$ was added and the resulting mixture was refluxed for $60 \mathrm{~min}$. The resulting solution was subsequently titrated against $0.5 \mathrm{M} \mathrm{HCl}$ with phenolphthalein as indicator. The resulting end point was obtained when the pink color changed into colorless. The same procedure was used for the blank. The Saponification value (SV) was then calculated using the expression: 
Saponification value (S.V.) $=56.1(\mathrm{~B}-\mathrm{S}) \times \mathrm{M}$ of $\mathrm{HCl} /$ Weight of sample

Where:

$\mathrm{B}-\mathrm{ml}$ of $\mathrm{HCl}$ required by blank 29

$\mathrm{S}-\mathrm{ml}$ of $\mathrm{HCl}$ required by sample

$\mathrm{N}$ - Molarity of $\mathrm{HCl}$

56.1- Molar mass of $\mathrm{KOH}$

\section{Determination of acid value}

Acid values of the various vegetable oils were also determined by ASTM method (ASTM - D 974(00). 0.2 to $0.5 \mathrm{~g}$ of sample were weighed into $250 \mathrm{ml}$ conical flask. $50 \mathrm{ml}$ of neutralized ethyl alcohol was added. The mixture was heated on a water bath to dissolve the sample. The solution was titrated against $0.1 \mathrm{M} \mathrm{KOH}$ using phenolphthalein as indicator. The acid value was determined after which the free fatty acid was calculated respectively as follows:

Acid value $=A \times M \times 56.1 / \mathrm{W}$

Where,

$\mathrm{A}=\mathrm{ml}$ of $0.1 \mathrm{M} \mathrm{KOH}$ consumed by sample

$\mathrm{M}=$ Molarity of $\mathrm{KOH}$

$\mathrm{W}=$ weight in grams of the sample

Then,

Free fatty acid $=$ Acid value $/ 2$

\section{Determination of peroxide value}

Weigh $5 \mathrm{~g} \mathrm{(} \pm 50 \mathrm{mg})$ sample into a $250 \mathrm{ml}$ stoppered conical flask. Add $30 \mathrm{ml}$ acetic acid chloroform solvent mixture and swirl to dissolve. Add $0.5 \mathrm{ml}$ saturated potassium iodide solution with a mohr pipette. Let stand for $1 \mathrm{~min}$ in dark with occasional shaking, then add about $30 \mathrm{ml}$ of water. Slowly titrate the liberated iodine with $0.1 \mathrm{~N}$ sodium thiosulphate solution, with vigorous shaking until yellow colour is almost gone. Using Add about $0.5 \mathrm{ml}$ starch solution as indicator and continue titration shaking vigorously to release all I 2 from $\mathrm{CHCl}_{3}$ layer until blue color disappears. If less than $0.5 \mathrm{ml}$ of $0.1 \mathrm{~N} \mathrm{Na}_{2} \mathrm{~S}_{2} \mathrm{O}_{3}$ is used repeat using $0.01 \mathrm{~N} \mathrm{Na}_{2} \mathrm{~S}_{2} \mathrm{O}_{3}$. Conduct blank determination (must be less than $0.1 \mathrm{ml} 0.1 \mathrm{~N}$ $\mathrm{Na}_{2} \mathrm{~S}_{2} \mathrm{O}_{3}$ ).

Calculation: Peroxide value expressed as milli equivalent of peroxide oxygen per $\mathrm{kg}$ sample $(\mathrm{meq} / \mathrm{kg})$ :

Peroxide value $=\underline{\text { Titre } \times \mathrm{N} \times 100}$

Weight of the sample

Where,

Titre $=\mathrm{ml}$ of Sodium Thiosulphate used (blank corrected).

$\mathrm{N}=$ Normality of sodium thiosulphate solution

\section{Determination of unsaponifiable matter}

Weigh accurately $5 \mathrm{~g}$ of well mixed oil/fat sample into a $250 \mathrm{ml}$ conical flask. Add $50 \mathrm{ml}$ of alcoholic potassium hydroxide solution. Boil the content under reflux air condenser for one hour or until the saponification is complete (complete saponification gives a homogeneous and transparent medium). Take care to avoid loss of ethyl alcohol during the saponification. Wash the condenser with about $10 \mathrm{ml}$ of ethyl alcohol. Transfer the saponified mixture while still warm to a separating funnel, wash the saponification flask first with some ethyl alcohol and then with cold water, using a total of 50 $\mathrm{ml}$ of water to rinse the flask. Cool to 20 to $25^{\circ} \mathrm{C}$. Add to the flask 50 $\mathrm{ml}$ of petroleum ether, shake vigorously, and allow the layers to separate.

Transfer the lower soap layer into another separating funnel and repeat the ether extraction for another 3 times using $50 \mathrm{ml}$ portions of petroleum ether. Some oils high in unsaponifiable matter, e.g., marine oils, may require more than three extractions to completely remove unsaponifiable matter. Wash the combined ether extract three times with $25 \mathrm{ml}$ portions of aqueous alcohol followed by washing with $25 \mathrm{ml}$ portions of distilled water to ensure ether extract is free of alkali (washing are no longer alkaline to phenolpthalen). Transfer ether solution to $250 \mathrm{ml}$ beaker, rinse separator with ether, and add risings to main solution. Evaporate to about $5 \mathrm{ml}$ and transfer quantitatively using several portions of ether to $50 \mathrm{ml}$ Erlen meyer flask previously dried and weighed. Evaporate ether. When all ether has been removed add 2 to $3 \mathrm{ml}$ acetone and while heating on steam or water bath completely remove solvent under a gentle air. To remove last traces of ether, dry at $100^{\circ} \mathrm{C}$ for 30 min till constant weight is obtained Dissolve residue in $50 \mathrm{ml}$ of warm ethanol which has been neutralized to a phenolpthalien end point. Titrate with $0.02 \mathrm{~N} \mathrm{NaOH}$.

\section{Calculation:}

Weight in $\mathrm{g}$ of the free fatty acids in the extract as oleic acid $=0.282$ VN

Where,

$\mathrm{V}=$ Volume in $\mathrm{ml}$ of standard sodium hydroxide solution

$\mathrm{N}=$ Normality of standard sodium hydroxide solution.

Unsaponifiable matter $=100(\mathrm{~A}-\mathrm{B}) / \mathrm{W}$

Where,

$A=$ Weight in $g$ of the residue.

$\mathrm{B}=$ Weight in $\mathrm{g}$ of the free fatty acids in the extract.

$\mathrm{W}=$ Weight in $\mathrm{g}$ of the sample

\section{Statistical analysis}

All data were presented as means \pm S.D. Statistical analysis for all the assays results were done using Microsoft Excel program (2007).

\section{RESULTS AND DISCUSSION}

Carum carvi oil has the low yield percentage with petroleum ether solvent shown in Table 1. Studies of various physical characteristics identify the practical importance and provide bases for suitability and utility of various oils of plants origin in daily life. Physical properties of oil like color, density, viscosity and refractive index are shown in Table 2.

Studies of various chemical characteristics identify the practical importance and provide bases for suitability and utility of various oils of plants origin in daily life. Chemical properties of oil like proximate analysis (ash, fatty acid, fiber, moisture, protein, carbohydrate) are shown in Table 3. Physiochemical properties of oil like (acid value, iodine value, saponification value, unsaponification matter, peroxide value) are shown in Table 4.

The physical properties of Carum carvi. $L$ seed oils are 
Table 1. Yield percentage of caraway (Carum carvi L.) oil.

\begin{tabular}{llccc}
\hline Name of plant & Part used & Weight of sample (g) & Volume of oil & Yield \% \\
\hline Carum carvi & Seeds & 500 & 22.5 & 4.5 \\
\hline
\end{tabular}

Table 2. Physical properties of caraway (Carum carvi L.) oil.

\begin{tabular}{llccccc}
\hline \multirow{2}{*}{ No } & \multirow{2}{*}{ Name } & Density & \multirow{2}{*}{ Refractive index } & \multirow{2}{*}{ Viscosity } & \multicolumn{3}{c}{ Color } \\
\cline { 5 - 7 } \cline { 4 - 6 } 1. Caraway (Carum carvi L.), oil & \multirow{2}{*}{$0.916 \pm 0.002$} & $1.465 \pm 0.002$ & $56.947 \pm 0.200$ & $1.4 \pm 0.1$ & $35.133 \pm 0.208$ & $0.1 \pm 0.00$ \\
\hline
\end{tabular}

Table 3. Proximate analysis of caraway (Carum carvi L.) oil.

\begin{tabular}{lcccccc}
\hline Name & Ach & Fatty acid & Fiber & Moisture & Protein & Carbohydrate \\
\hline $\begin{array}{l}\text { Caraway (Carum } \\
\text { carvi L.) oil }\end{array}$ & $9.29 \pm 0.52$ & $1.67 \pm 0.16$ & $46.85 \pm 0.49$ & $3.205 \pm 0.021$ & $31.12 \pm 0.46$ & $7.87 \pm 0.67$ \\
\hline
\end{tabular}

Table 4. Physiochemical analysis of caraway (Carum carvi L.) oil.

\begin{tabular}{lccccc}
\hline Name & Acid value & Peroxide value & Saponification value & Unsaponification metter & lodine value \\
\hline $\begin{array}{l}\text { Caraway (Carum carvi L.) } \\
\text { oil }\end{array}$ & $0.63 \pm 1.14$ & $4.45 \pm 0.48$ & $188.303 \pm 1.38$ & $3.01 \pm 0.47$ & $98.737 \pm 0.78$ \\
\hline
\end{tabular}

Table 5. Comparative between sample of study and literature of Carum carvi. $L$ seeds.

\begin{tabular}{lcc}
\hline Test & In this study & Review literature \\
\hline Moisture & $3.205 \pm 0.021$ & 9.87 \\
Protein & $31.12 \pm 0.46$ & 19.77 \\
Fiber & $46.85 \pm 0.49$ & 14.59 \\
Carbohydrate & $7.87 \pm 0.67$ & 40.9 \\
Fiber & $46.85 \pm 0.49$ & 38.0 \\
Fatty acid & $1.67 \pm 0.16$ & 0.62 \\
\hline Source: USDA national nutrient database for standard reference release \\
24 (2011).
\end{tabular}

presented in Table 2. The density of the reviewed seed oils is found to be in the range of 0.847 in cotton seed oil to 1.160 in cashew nut seed oil. Density of seed/vegetable oils is dependent on their fatty acid composition, minor components and temperature (Fakhri and Qadir, 2011). The difference in the density of the reviewed oils may be due to the refined and unrefined characteristics of the oils. The density of Carum carvi. L seeds oil are acceptable according to this studies.

The viscosity of the reviewed oils (56.947). The more viscous oil is, the better its use as lubricant (Belewu et al., 2010). The low viscosity values indicate that they are light and so probably highly unsaturated; the high value might be as a result of suspended particles still present in the crude oil sample (Nangbes et al., 2013).

The refractive index was (1.465) in Carum carvi. L seeds oil. Refractive index of an oil is the ratio of speed of light at a defined wavelength to its speed in the oil/fat itself. This value varies with wavelength and temperature, the degree and type of unsaturation, the type of substitutions of component fatty acids and with accompanying substances. Refractive index is widely used in quality control to check for the purity of materials and to follow hydrogenation and isomerization (Hoffman, 1986). Most of the seed oils reviewed have their refractive index values within the acceptable range of 
1.4677 to 1.4707 for virgin, refined and refined-pomace oils according to Codex Standards for fats and oils from vegetable/plant sources (CODEX-STAN, 1999).

The proximate analysis of carum carvi. L. seed oils are presented in Table 3. The moisture content of carum carvi seeds was determined by using oven. $100 \mathrm{~g}$ of fresh seeds was taken and placed in oven. At 6 to $12 \mathrm{~h}$ in 100 to $105^{\circ} \mathrm{C}$, only 96.78 to $96.81 \mathrm{~g}$ left. This indicates that above (3.22 to $3.19 \%)$ weight of this plant was water. The fatty acid of Carum carvi. L. seeds were found to be (1.78). High concentrations of free fatty acids are undesirable in crude vegetable oils because they result in large losses of the neutral oil during refining. In crude fat, free fatty acids estimate the amount of oil that will be lost during refining steps designed to remove fatty acids (Weiss, 1983).

The physicochemical properties of Carum carvi. L. seed oils are presented in Table 4. Acid value gives an indication of the quality of fatty acids in oil. In this study the acid values is (0.63). This value however accounted for the presence of free fatty acids in the oils as an indicator of the presence and extent of hydrolysis by lipolytic enzymes and oxidation. Low acid value in oil indicates that the oil will be stable over a long period of time and protect against rancidity and peroxidation. High acid value in oil (e.g. luffa gourd) showed that the oil may not be suitable for use in cooking (edibility), but however, be useful for production of paints, liquid soap and shampoos (Akintayo, 2004; Aremu et al., 2006a).

The peroxide value of the oil under this study accounted 4.45. High values of P.V are indicative of high levels of oxidative rancidity of the oils and also suggest absence or low levels of antioxidant; certain antioxidants may, however, be used to reduce rancidity such as propygadlate and butyl hydroxyl anisole (Kyari, 2008).

The saponification value is 188.303. The low saponification value is an indication that the oil may not be suitable for soap making, oil-based ice-cream and shampoos. It has been reported by Pearson (1976) that oils with high saponification values contain high proportion of lower fatty acids. Therefore, the low saponification value of some oils under reviewed indicated that they contain high proportion of higher fatty acid and can be regarded as non-edible oils.

The value for unsaponifiable matter is 3.01. High unsaponifiable matter content of fats and oils has been reported to be an indication of adulteration or contamination. This may be due to the presence of fuel or lubricating oils in the oil sample (Ihekoronye and Ngoddy, 1985).

The iodine value is a measure of the degree of unsaturation and it is an identity characteristic of seed oils, making it an excellent raw materials for soaps cosmetics industries (Morrison, 1995). For the reviewed oils, iodine value is 93.737 . The iodine value could be used to quantify the amount of double bond present in the oil which reflects the susceptibility of the oil to oxidation. Good drying oil should have iodine value of
130 and above.

\section{Conclusion}

Carum carvi. L. plant in Sudan has good yield of seeds. According to the results obtained in this study, the following general conclusion can be derived Sudanese carum carvi. L. seeds are rich sources of oils containing diverse group of phytochemicals. The study suggests that the seeds has good source of protein for human and animal consumption. It is also a good source of fertilizer and a possible good oil yield that has wide variety of uses.

\section{REFERENCES}

Akintayo ET, 2004. Characteristics and composition of Parkia biglobbossa and Jatropha curcas oils and cakes. Bioresour Technol, 92: 307-310.

Aremu MO, Olaofe O, Akintayo ET, 2006a. Chemical composition and physicochemical characteristics of two varieties of bambara groundnut (Vigna subterrenea) flours. J Appl Sci, 6(9): 1900-1903.

Belewu MA, Adekola FA, Adebayo GB, Ameen OM, Muhammed NO, Olaniyan AM, Adekola OF, Musa AK, 2010. Physico-chemical characteristics of oil and biodiesel from Nigerian and Indian Jatropha curcas seeds. Int J Biol Chem Sci, 4(2): 524-529.

Bown D, 1995. Encyclopaedia of Herbs and Their Uses. Dorling Kindersley, London.

Chevallier A, 1996. The Encyclopedia of Medicinal Plants. Dorling Kindersley. London.

Engler CR, Johnson LA, 1983. Effects of processing and chemical characteristics of plant oils on performance of an indirect-injection diesel engine. J Am Oil Chem Soc, 60(8): 1592-1596.

Eze SOO, 2012. Physicochemical properties of oil from some selected underutilized oil seeds available for biodiesel preparation. Afr $\mathrm{J}$ Biotechnol, 11(42): 10003-10007

Fakhri NA, Qadir HK, 2011. Studies on various physico-chemical characteristics of some vegetable oils. J Environ Sci Eng, 5: 844849.

Foster S, Duke JA, 1990. A Field Guide to Medicinal Plants: Eastern and Central North America. Houghton Mifflin Co, Boston.

Gordon M, 1993. Fats and Fatty Foods, In: Ranken, M. D. and Kill, R. C. (eds). Food Industries Manual. 23rd ed., Blackie Academic and Professional, London, 288-327.

Grieve M, 1984. A Modern Herbal. Penguin Books, Harmondsworth, London.

Gruenwald J, Brendler T, Jaenicke C, 2004. PDR for Herbal Medicines, 3rd Edition. Medical Economics Company, pp. 245-246.

Ihekoronye Al, Ngoddy PO, 1985. Integrated Food Science and Technology. Macmilian Publishers, New York. pp. 296-301.

Indian Standards, 2011. Spices and condiments-caraway seedsspecification, (First Revision). Bureau of Indian Standards, Manakbhavan, Bahadur Shah Zafarmarg, New Delhi.

Kallio H, Kerrola K, Alhonmaki P, 1994. Carvone and limonene in caraway fruits (Carum carvi L.) analyzed by supercritical carbon dioxide extraction-gas chromatography. J Agric Food Chem, 42: 2478-2485.

Kochhar SL, 1998. Economic Botany in the Tropics. 2nd Edition, Macmillan India Ltd, pp $354-355$.

Kyari MZ, 2008. Extraction and characterization of seed oils. Int Agrophys, 22: 139-142.

Laribi B, Kouki K, Mougou A, Marzouk B, 2010. Fatty acid and essential oil composition of three Tunisian caraway (Carum carvi L.) seed ecotypes. J Sci Food Agric, 90(3):391-396.

Morrison WH, Hamilton RJ, Kalu C, 1995. Sun flower seed oil. In: R.J. Hamilton, (ed.) Developments in oils and fats. Blackie Academic and Professional, Glasgow. pp: 132-152. 
Nangbes JG, Nvau JB, Buba WM, Zukdimma AN, 2013. Extraction and characterization of castor (Ricinus communis) seed oil. Int J Eng Sci, 2(9): 105-109.

Nielson SS, 1994. Introduction to the chemical analysis of foods. Chapman and Hall, New York, pp. $93-207$.

Nourrechni H. Teoh BC, Clement LD, 1992. Viscocity of vegetable oils and fatty acids. J Am Chem Soc, 69: 1184-1188.

Oderinde KA, Ajayi IA, Adewuyi A, 2009. Characterization of seed and seeds oil of Hura crepitans and the kinetics of degradation of the oil during heating. Elect J Environ Agric Food Chem, 8(3): 201-208.

Overhults DG, White GM, Hamilton HE, Ross IJ, 1973. Drying soybeans with heated air. Trans ASAE, p. 112-113.

Weiss TJ, 1983. Physical and chemical properties of fats and oils. In food oils and their uses. AVI Publ. Co. Inc. Westport.com. USA 2nd edition, pp. $25-84$.
Citation: Abdalaziz MN, Ali MM, Garbi MI, Kabbashi AS, 2017. Physiochemical and proximate analysis of Carum carvi. L. Adv Med Plant Res, 5(2): 21-28. 